\title{
IMPLEMENTASI MODEL PEMBELAJARAN DISCOVERY LEARNING DALAM PENINGKATAN KEMAMPUAN SISWA: STUDI KASUS DI MTSN 2 PIDIE JAYA
}

\section{IMPLEMENTATION OF DISCOVERY LEARNING MODEL IN IMPROVING STUDENT ABILITY: A CASE STUDY ON MTSN 2 PIDIE JAYA}

\author{
Cut Qadriah' \\ ${ }^{1}$ MTSN 2 Pidie Jaya, Provinsi Aceh, Indonesia.
}

E-mail: cut.qadriah21@gmail.com

\begin{abstract}
ABSTRAK
Penelitian implementasi model pembelajaran discovery learning dalam peningkatan kemampuan siswa: studi kasus di MTSN 2 Pidie Jaya bertujuan untuk mengetahui kemampuan siswa memahami materi kugapai rezekimu dengan ikhtiarku dalam upaya meningkatkan hasil pembelajaran. Penelitian ini melibatkan siswa kelas VIII A semester ganjil tahun pelajaran 2019/2020 MTsN 2 Pidie Jaya terdiri dari 23 siswa perempuan dan 10 siswa laki-laki dan 13 perempuan dilakukan dalam dua siklus. Data yang diperoleh dalam penelitian ini meliputi hasil belajar siswa yang diambil dari pemberian soal tes pada akhir siklus, kemampuan guru dalam pembelajaran yang diambil dari lembar observasi, aktivitas siswa dalam pembelajaran yang diambil dari lembaran observasi, data tentang refleksi siswa terhadap pembelajaran yang diambil dari angket pada setiap akhir siklus. Hasil penelitian pada siklus I menunjukkan rata-rata hasil belajar siswa sebesar 64,06 dan persentase ketuntasan belajar sebesar 65,62\%. Pada siklus II rata-rata hasil belajar siswa menunjukkan nilai sebesar 79.02, dan persentase ketuntasan belajar sebesar 93,75\%. Hal ini menunjukkan bahwa model pembelajaran discovery learning dapat meningkatkan hasil belajar dan aktivitas siswa kelas VIII. Model pembelajaran ini mampu mewujudkan suasana pembelajaran yang aktif, inovatif, kreatif, dan menyenangkan.
\end{abstract}

Kata Kunci: Discovery learning, mtsn 2 pidie jaya, aceh, siswa. 


\begin{abstract}
Research on the implementation of discovery learning models in improving students' abilities: a case study on MTSN 2 Pidie Jaya aims to determine the ability of students to understand kugapai rezekimu dengan ikhtiarku to improve learning outcomes. The study involved students of class VIII A in the odd semester of the 2019/2020 academic year at MTsN 2 Pidie Jaya consisting of 23 female students and 10 male and 13 female students carried out in two cycles. The data obtained include student learning outcomes taken from giving test questions at the end of the cycle, teacher abilities in learning taken from observation sheets, student activities in learning taken from observation sheets, data about students' reflections on learning taken from questionnaires. at the end of each cycle. The results of the research in the first cycle showed that the average student learning outcomes were 64.06 and the percentage of learning completeness was $65.62 \%$. In the second cycle the average student learning outcomes showed a value of 79.02, and the percentage of learning completeness was 93.75\%. The shows that the discovery learning model can improve the learning outcomes and activities of class VIII students. The model is able to create an active, innovative, creative, and fun learning.
\end{abstract}

Keyword: Discovery learning, MTSN, Aceh, Pidie Jaya, Student.

\title{
PENDAHULUAN
}

Dalam firman Allah QS.Al-Dzariyat (51) : 56, QS.Al-Baqarah(2):31, dan QS.AlHujarat (49): 13. Pendidikan mempunyai tujuan untuk membantuk kepribadian seorang muslim yang dilandasi keimanan dan ketakwaan sehingga dapat menjadi insan muslim yang sempurna (insan kamil). Pendidikan nasional bertujuan untuk meningkatkan keimanan dan ketaqwaaan serta berakhlak mulia dalam rangka mencerdaskan kehidupan bangsa. Untuk mengwujudkan fungsi tersebut pemerintah mengembangkan sistem pendidikdn nasional sebaagaimana tercantum dalam UndangUndang Nomor 20 tahun 2003 pasal 4 menyebutkan bahwa standar nasional pendidikan bertujuan untuk menjamin mutu pendidikan nasional dalam rangka mencerdaskan kehidupan bangsa dan membentuk watak yang mulia.

Salah satu faktor penentu kualitas pendidikan adalah sekolah. Proses pembelajaran yang baik di sekolah akan menghasilkan lulusan yang bermutu yang dapat dijadikan sebagai salah satu indikator keberhasilan pendidikan. Pembelajaran dapat dikatakan efektif apabila mencapai tujuan yang diharapkan. Ketercapaian tujuan pembelajaran dapat dilihat dari nilai yang diperoleh siswa. (Slamet, 2004). 
Hasil belajar yang rendah menunjukkan bahwa proses pembelajaran belum berjalan secara efektif.

Seiring dengan perkembangan dan kemajuan teknologi, maka berkembang pula tuntutan masyarakat terhadap kualitas pendidikan. Untuk memenuhi kebutuhan pendidikan yang berkualitas, diperlukan tenaga kependidikan terutama guru yang berkualitas pula, karena pendidikan yang berkualitas dan bermutu hanya dapat dijalankan oleh guru profesional. Guru yang profesional adalah guru yang memiliki standar akedemik dan standar profesi. Kinerja profesional merupakan akumulasi karya guru yang memiliki standar pedagogik, kepribadian, sosial, dan profesionalisme. Seluruh kompetensi ini harus ditunjukkan dalam bentuk bukti formal sesuai latar belakang pendidikan profesional.

Salah satu bukti formal yang dapat ditunjukkan oleh guru dan dapat diukur apakah guru tersebut termasuk dalam kriteria guru profesianal adalah melalui kegiatan pembelajaran. Pembelajaran yang dimaksudkan di sini adalah pembelajaran yang dapat mendorong siswa agar belajar aktif, inovatif, kreatif, efektif, dan menyenangkan. Untuk mewujudkan suasana demikian, guru sebagai pelaku utama dalam perubahan pembelajaran di harus memiliki komitmen yang tinggi untuk melaksanakan tugas dan bertanggung jawab terhadap mutu pendidikan.
Materi kugapai rezekimu dengan ikhtiarku di MTsN 2 Pidie Jaya dipelajari di kelas VIII pada KD memahami isi kandungan QS. Quraisy dan QS. Al-Insyirah tentang ketentuan rezeki Allah. Berdasarkan pengalaman penulis sebagai guru di MTsN 2 Pidie Jaya untuk memahami materi tersebut siswa merasa kesulitan karena kurang pemahaman dalam menelaah ayat-ayat AlQur'an secara langsung. Hal ini berdasarkan pengamatan penulis sebagai guru di MTsN 2 Pidie Jaya serta hasil ujian yang belum memenuhi nilai seperti yang diharapkan.

Oleh karena itu penulis berusaha untuk melakukan suatu model pembelajaran yang bertujuan untuk dapat meningkatkan motivasi dan hasil belajar siswa di MTsN 2 Pidie Jaya

Model-model pembelajaran merupakan sebuah kerangka teori, sebuah teori belajar. Guru yang profesional tidak hanya menguasai sejumlah materi pembelajaran, tetapi juga terampil dalam menggunakan model-model pembelajaran yang tepat dan sesuai dengan karakteristik mata pelajaran serta situasi pada saat materi pelajaran tersebut harus disajikan. Selain itu, guru juga harus memilih model pembelajaran yang tepat agar pembelajaran menjadi aktif, inovatif, kreatif, efektif, dan peserta didik memiliki pengalaman belajar sesuai dengan pendekatan saintifik seperti mengamati, menanya, mengumpulkan informasi, mengasosiasi dan mengomunikasikan. 
Pada Permendikbud nomor 103 tahun 2014, model pembelajaran yang disarankan dalam pembelajaran Al-Qur'an Hadits diantaranya model discovery learning, project based learning, problem based learning dan inquiry. Masing-masing model mempunyai sintak pembelajaran, keunggulan dan kelemahan, dan cara penerapan yang berbeda.

Discovery learning adalah salah satu model pembelajaran yang dapat mendorong peserta didik untuk mengidentifikasi apa yang ingin diketahui dilanjutkan dengan mencari informasi sendiri kemudian mengorgansasi atau membentuk (konstruktif) apa yang mereka ketahui dan mereka pahami dalam suatu bentuk akhir.

Penggunaan discovery learning, ingin merubah kondisi belajar yang pasif menjadi aktif dan kreatif. Mengubah pembelajaran yang teacher oriented ke student oriented. Merubah model ekspository siswa hanya menerima informasi siswa dituntut untuk melakukan berbagai kegiatan menghimpun informasi, membandingkan, mengelompokkan, analisis, mengintegrasikan, dan mengornasisasikan bahan serta membuat kesimpulan.

Bruner mengatakan bahwa proses belajar akan berjalan dengan baik dan kreatif jika guru memberikan kesempatan kepada siswa untuk menemukan suatu konsep,teori, aturan, atau pemahaman melalui contoh-contoh yang ia jumpai dalam kehidupannya (Budiningsih, 2005:41). Pada akhirnya yang menjadi tujuan dalam discovery learning menurut Bruner adalah hendaklah guru memberikan kesempatan kepada muridnya untuk menjadi seorang problem solver, seorang scientist, historin, atau ahli matematika. Dan melalui kegiatan tersebut siswa akan menguasainya, menerapkan, serta menemukan hal-hal yang bermanfaat bagi dirinya.

\section{METODE PENELITIAN}

\section{A. Lokasi Penelitian}

Penelitian ini dilaksanakan di MTsN 2 Pidie Jaya Kabupaten Pidie Jaya pada kelas VIII A dengan Kompetensi Dasar (KD) meliputi beberapa hal yaitu, memahami isi kandungan Q.S Quraisy dan Q.S Al -Insyirah tentang ketentuan rezeki Allah, simulasi isi kandungan Q.S Quraisy danQ.S Al - Insyirah tentang ketentuan Rezeki Allah berdasarkan hasil studi literatur dalam bentuk laporan tertulis.

\section{B. Subjek Penelitian}

Subjek penelitian ini adalah siswa kelas VIII A semester 1 tahun pelajaran 2019/2020 yang berjumlah 23 siswa, terdiri dari 10 siswa putra dan 13 siswa putri yang karakteristiknya berdasarkan pengamatan ialah memiliki ratarata hasil belajar siswa yang bervariasi namun demikian memiliki tingkat kecerdasan hampir sama, sehingga perlu suasana pembelajaran yang menyenangkan

C. Sumber dan Jenis Data

1. Sumber Data 
Sumber data penelitian adalah siswa dan guru.

\section{Jenis Data}

Jenis data meliputi tentang hasil belajar, keaktifan siswa dalam kelompok, kinerja guru dalam pembelajaran, dan tanggapan siswa terhadap pembelajaran.

D. Teknik dan Alat Pengumpul Data

1. Teknik Pengumpulan Data

Teknik pengumpulan dilakukan melalui beberapa tahapan yaitu, hasil belajar diambil dengan memberikan evaluasi pada setiap akhir siklus, kinerja guru dalam pembelajaran dan aktivitas siswa dalam kelompok diambil dengan menggunakan lembar observasi, dan tanggapan siswa terhadap pembelajaran dengan menggunakan angket refleksi siswa terhadap pembelajaran.

\section{Alat Pengumpulan Data}

Alat pengumpulan data terdiri dari lembar tes hasil belajar, lembar observasi aktivitas siswa dalam kelompok, lembar observasi guru dalam proses pembelajaran, lembaran kuisioner refleksi siswa terhadap pembelajaran, dan catatan lapangan.

\section{E. Validasi Data}

\section{Tes Hasil Belajar}

Soal tes disusun berdasarkan tujuan pembelajaran yang akan dicapai, digunakan untuk mengukur hasil belajar siswa pada materi Sistem Kugapai rezekimu dengan Ikhtiarku.
Bentuk tes yang diberikan adalah tes tulisan berbentuk pilihan ganda.

2. Observasi aktivitas siswa dan guru.

Validasi data observasi ini adalah merupakan triangulasi antara siswa, guru yang melaksanakan PBM dan guru pengamat.

F. Analisis Data

Dalam penelitian ini, data dianalisis dengan menggunakan tehnik analisis deskriptif.

1. Hasil belajar siswa dianalisis dengan analisis diskriptif komparatif yaitu dengan membandingkan nilai tes antar siklus maupun dengan indikator keberhasilan.

2. Observasi aktivitas siswa dan guru saat kegiatan belajar mengajar dianalisis dengan analisis deskriptif berdasarkan hasil observasi dan refleksi.

\section{HASIL PENELITIAN DAN PEMBAHASAN}

Dalam penelitian ini, peneliti telah menyusun rencana pelaksanaan pembelajaran pada KD yaitu: Memahami isi kandungan Q.S Quraisy dan Q.S Al -Insyirah tentang ketentuan Rezeki Allah dan simulasi isi kandungan Q.S Quraisy dan Q.S Al -Insyirah tentang ketentuan Rezeki Allah, menyiapkan instrumen penelitian (lembar observasi guru dan siswa, kuisioner angket refleksi siswa, lembar tes hasil belajar siswa), menyiapkan lembar kerja peserta didik (LKPD), merancang pembentukan kelompok, setiap kelompok terdiri dari 4 siswa dengan memperhatikan penyebaran kemampuan siswa 
berdasarkan nilai ulangan materi sebelumnya, dan mengembangkan skenario pembelajaran Discovery learning sebagaimana RPP terlampir.

Selanjutnya, ketika peneliti melakukan tindakan pada siklus I, guru melakukan apersepsi, memberikan motivasi untuk mengarahkan siswa pada materi pembelajaran , menyampaikan tujuan pembelajaran yang akan dicapai, menjelaskan langkah kerja model pembelajaran discovery learning mengarahkan siswa agar duduk sesuai kelompok yang ditentukan.

Guru menampilkan ilustrasi contoh rezeki Allah. Siswa diminta mengamati dan menganalisis gambar sebagai pemberian stimulus memasuki kegiatan inti

Guru membagikan LKPD, kepada setiap kelompok untuk didiskusikan sebagai bahan yangn akan dipelajari. Alhamdulillah, di kelas VIII A sebahagian besar siswa sudah memiliki buku pegangan Al-Qur'an Hadits, jadi hal ini mempermudah untuk membahas materi pelajaran. Siswa bersama kelompoknya berdiskusi mengerjakan LKPD setiap kelompok diharuskan memastikan semua anggotanya dapat memahami diskusi tersebut. Pada saat siswa berdiskusi, guru berkeliling mengarahkan dan membimbing bila ada kelompok yang mengalami kesulitan, serta memotivasi seluruh siswa untuk berpartisipasi dalam diskusi kelompok.
Setelah waktu diskusi selesai, siswa harus mempresentasikan hasil diskusi kelompok. Guru meminta kelompok memperhatikan dan bila kurang jelas diberi kesempatan bertanya, jika terjadi perbedaan pendapat maka kelompok lain diberi kesempatan untuk menanggapi (memberi masukan dan jawaban). Selanjutnya, dilakukan diskusi kelas untuk membuat kesimpulan di akhir kegiatan, sekaligus menentukan kelompok mana yang terbaik menurut pengamatan siswa dengan memberi kesempatan pada masing-masing ketua kelompok menilai hasil kerja kelompok. Peneliti memberikan penghargaan dan siswa senang dan bertepuk tangan

Pada saat yang sama, kolaborator melakukan pengamatan dengan mengisi instrumen yang sudah disiapkan meliputi: pengamatan kegiatan guru, pengamatan kegiatan siswa saat kegiatan belajar mengajar.

Di akhir siklus, peneliti memberikan tes hasil belajar dan meminta siswa mengisi angket refleksi terhadap pembelajaran yang telah dilakukan. Hasil yang didapat dari pengamatan ini adalah sebagai berikut.

\section{a. Hasil Observasi Kinerja Guru}

Pengamatan kemampuan guru dalam pengelolaan pembelajaran pada pertemuan pertama siklus I dengan skor terendah 2 dan skor tertinggi 3 (lampiran).

b. Hasil Observasi Aktivitas Siswa 
Pengamatan aktivitas siswa dalam pembelajaran pada siklus 1 sudah baik dengan skor terendah 2 dan skor tertinggi 3

c. Hasil Belajar Siswa

Setelah dilakukan analisis data hasil tes siklus I dengan materi pelajaran Struktrur dan fungsi alat-alat ekresi, diperoleh data siswa yang tuntas sebanyak 15 orang $(65,62 \%)$, siswa yang tidak tuntas sebanyak 8 orang $(34,47 \%)$ dengan nilai tertinggi 90 dan nilai terendah 40 ( tabel 4 ).

\section{d. Hasil Analisis Angket Siswa}

Tanggapan siswa tentang pembelajaran dilakukan pada setiap akhir siklus. Hasil tanggapan siswa atas pembelajaran yang telah dilakukan pada siklus I dapat dilihat pada tabel berikut:

Tabel 3, Hasil Angket Refleksi Siswa Siklus I.

\begin{tabular}{|c|c|c|c|}
\hline No. & Aspek yang Diamati & \begin{tabular}{|l|} 
Frekuensi \\
Jawaban
\end{tabular} & Persentase \\
\hline \multirow[t]{4}{*}{1.} & $\begin{array}{l}\text { Pemyataan siswa mengenai pembelajaran } \\
\text { dengan model Discoveri Leaming }\end{array}$ & & \\
\hline & A. Menyenangkan & 20 & $84,37 \%$ \\
\hline & B. Tidak menyenangkan & - & - \\
\hline & C. Ragu-ragu & 3 & $15,62 \%$ \\
\hline \multirow[t]{4}{*}{2.} & $\begin{array}{l}\text { Pemyataan siswa mengenai pembelajaran } \\
\text { yang dilakukan dengan kerja kelompok. }\end{array}$ & & \\
\hline & A. Menyenangkan & 17 & $81,25 \%$ \\
\hline & B. Tidak menyenangkan & 4 & $12,5 \%$ \\
\hline & C. Ragu-ragu & 2 & $6,25 \%$ \\
\hline \multirow[t]{4}{*}{3.} & $\begin{array}{l}\text { Pemyataan siswa bahwa model Discover } \\
\text { Leaming membuat siswa berani } \\
\text { mengemukakan pendapat. }\end{array}$ & & \\
\hline & A. $\mathrm{Ya}$ & 13 & $56,25 \%$ \\
\hline & B. Tidak & 4 & $18,75 \%$ \\
\hline & C. Ragu-ragu & 6 & $32 \%$ \\
\hline \multirow[t]{4}{*}{4.} & $\begin{array}{l}\text { Pemyataan siswa bahwa pembelajaran } \\
\text { denganmodel Discoveri Leamingmembuat } \\
\text { siswa mudah memahami pelajaran }\end{array}$ & & \\
\hline & A. $\mathrm{Ya}$ & 17 & $75 \%$ \\
\hline & B. Tidak & 3 & $12,5 \%$ \\
\hline & C. Ragu-ragu & 3 & $12,5 \%$ \\
\hline \multirow[t]{4}{*}{5.} & $\begin{array}{l}\text { Pemyataan siswa mengalami kesulitan } \\
\text { dalam mengikuti pembelajaran }\end{array}$ & & \\
\hline & A. $\mathrm{Ya}$ & 3 & $12,5 \%$ \\
\hline & B. Tidak & 18 & $78,13 \%$ \\
\hline & C. Ragu-ragu & 2 & $9,37 \%$ \\
\hline
\end{tabular}

\section{A. Pembahasan Siklus I \\ a. Aktivitas Guru}

Dalam kegiatan inti, yang dilakukan guru meliputi mengorientasi siswa dalam pembelajaran, dalam hal ini guru memberikan bimbingan kepada kelompok yang mengalami kesulitan. Siswa dalam kelompoknya melakukan kegiatan dengan bimbingan guru, namun demikian bimbingan guru masih belum merata pada setiap kelompok. Guru lebih banyak memberikan bimbingan kepada kelompok yang aktif bertanya, sedangkan kelompok yang cenderung pasif hanya mendapat bimbingan guru secara sekilas. Selain itu, guru belum dapat mengalokasikan waktu secara baik, ini dikarenakan belum terbiasanya guru dalam menerapkan model pembelajaran Discoveri Learning ( DL).

Pada kegiatan penutup guru membimbing siswa dalam menarik kesimpulan. Namun dalam menarik kesimpulan kebanyakan masih dilakukan oleh guru, sehingga siswa belum terbiasa berpikir sendiri. Secara umum, pada siklus I ini guru masih mendominasi pembelajaran.

Penilaian aktivitas guru pada siklus I cukup baik. Persiapan guru sudah cukup matang dan selama proses pembelajaran berlangsung guru sudah berusaha untuk menerapkan model pembelajaran Discoveri Learning sesuai dengan RPP yang telah dibuat. Namun hal ini perlu ditingkatkan lagi pada siklus II dengan perbaikan-perbaikan seperti pemerataan bimbingan pada setiap kelompok, serta memberi kesempatan pada siswa untuk 
terbiasa berpikir sendiri. Selain itu diupayakan untuk merancang kembali alokasi waktu yang tepat pada skenario pembelajaran sehingga sesuai dengan alokasi waktu pada saat di lapangan.

\section{Keaktifan Siswa}

Pada siklus I, antusias dan motivasi siswa dalam mengikuti pembelajaran sudah baik karena dorongan dan pemberian motivasi oleh guru. Untuk kerja kelompok menunjukkan aktivitas, seperti diskusi dan tanya jawab antar teman dalam kelompok, serta memberi pendapat tentang hasil yang dipresentasikan juga sudah baik. Selain itu dalam mengkaji ulang/melakukan evaluasi dan membuat kesimpulan juga semakin meningkat.

Berdasarkan hasil lembar observasi aktivitas siswa, keaktifan siswa pada siklus 1 cukup baik. Hasil ini sudah sesuai dengan indikator kaberhasilan yang ditetapkan sebanyak $70 \%$.

Walaupun demikian perlu adanya perbaikan sekaligus peningkatan dengan memberikan dorongan motivasi kepada siswa yang masih sungkan mengemukakan pendapat, untuk lebih bersungguh-sungguh dalam mengerjakan tugas, menyatukan pendapat, tidak merasa malu jika salah menjawab soal,serta melakukan diskusi secara aktif dan memberi pujian bagi siswa yang bertanya dan menjawab pertanyaan. Guru harus mampu memberi perhatian serta motivasi terhadap kegiatan siswa dalam kelompoknya.
Permasalahan ini akan diupayakan perbaikan pada siklus II.

\section{Hasil Belajar Siswa}

Pada siklus I, hasil belajar siswa belum mencapai indikator keberhasilan karena siswa yang tuntas $65,62 \%$ masih banyak yang belum tuntas $34,37 \%$ sehinnga. perlu diadakan upaya perbaikan sekaligus peningkatan pada siklus II dengan memotivasi siswa untuk lebih aktif dalam pembelajaran. Rinciannya dapat dilihat pada tabel berikut:

Tabel 4. Ketuntasan Belajar Siswa Hasil Siklus I

\begin{tabular}{|c|c|c|c|}
\hline \multirow{2}{*}{ No } & \multirow{2}{*}{ Ketuntasan } & \multicolumn{2}{|c|}{ Jumlah Siswa } \\
\hline & & Jumlah & Persen \\
\hline 1 & Tuntas & 18 & $65,62 \%$ \\
\hline 2 & Belum Tuntas & 5 & $34,37 \%$ \\
\hline Jum & & 23 & $\% \quad 100$ \\
\hline
\end{tabular}

Berdasarkan tabel, jumlah yang tuntas adalah 21 siswa $(65,62 \%)$, sedangkan yang belum tuntas mencapai 11 siswa $(34,37 \%)$.

Tabel 5. Keadaan Nilai Hasil Tes Siklus I

\begin{tabular}{|l|l|l|}
\hline No & Keterangan & Nilai \\
\hline 1 & Nilai Tertinggi & 90 \\
\hline 2 & Nilai Terendah & 40 \\
\hline 3 & Nilai Rata-rata & 64,06 \\
\hline
\end{tabular}

Berdasarkan tabel 10, menunjukkan bahwa nilai tertinggi adalah 90 , nilai terendah 40, sedangkan rata-rata kelas adalah 64,06

Hasil Angket Siswa

Berdasarkan Tabel 3, secara umum siswa memberikan respon positif atas pembelajaran yang telah dilakukan. Sebanyak 84,37 \% siswa 
mengaku merasa senang dengan pembelajaran discovery learning, $75 \%$ siswa mudah memahami materi, 56,25\% terdorong untuk berani mengemukakan pendapat walaupun terdapat $12,5 \%$ siswa yang masih mengalami kesulitan dalam mengikuti pembelajaran,

\section{$18,75 \%$ kurang berani berpendapat}

C. Hasil Penelitian dan Pembahasan Siklus II

\section{Hasil Penelitian Siklus II}

Dalam perencanaan tindakan kelas ini, peneliti telah menyusun rencana pelaksanaan pembelajaran pada KD 3.2. Memahami isi kandungan Q.S Quraisy dan Q.S Al -Insyirah tentang ketentuan Rezeki Allah dan 4.2. Mensimulasi isi kandungan Q.S Quraisy dan Q.S Al -Insyirah tentang ketentuan Rezeki Allah menyiapkan instrumen penelitian (lembar observasi guru dan siswa, kuisioner angket refleksi siswa, lembar tes hasil belajar siswa), menyiapkan lembar kerja siswa (LKPD), merancang pembentukan kelompok, setiap kelompok terdiri dari 4 siswa dengan memperhatikan penyebaran kemampuan siswa berdasarkan nilai ulangan materi sebelumnya, dan mengembangkan skenario pembelajaran discovery learning.

Selanjutnya, ketika peneliti melakukan tindakan pada siklus II, guru melakukan apersepsi, memberikan motivasi untuk mengarahkan siswa tentang materi yang didiskusikan , menyampaikan tujuan pembelajaran yang akan dicapai, , mengingatkan kembali SIntaks model pembelajaran, mengarahkan siswa agar duduk sesuai kelompok yang ditentukan.

Guru membagikan LKPD kepada setiap siswa sebagai bahan yang akan dipelajari. Siswa bersama kelompoknya berdiskusi mengerjakan LKPD setiap kelompok diharuskan memastikan semua anggotanya dapat memahami diskusi tersebut. Pada saat siswa berdiskusi, guru berkeliling mengarahkan dan membimbing bila ada kelompok yang mengalami kesulitan, serta memotivasi seluruh siswa untuk berpartisipasi dalam diskusi kelompok.

Setelah waktu diskusi selesai, guru menentukan kelompok yang harus mempresentasikan hasil diskusi. Kelompok lain diminta memperhatikan jalannya presentasi dan bila kurang jelas diberi kesempatan bertanya, jika terjadi perbedaan pendapat maka kelompok lain diberi kesempatan untuk menanggapi (memberi masukan dan jawaban). Guru menyimak dan mencatat pertanyaan siswa untuk diklarifikasi Selanjutnya, dilakukan diskusi kelas untuk membuat kesimpulan di akhir kegiatan, sekaligus menentukan kelompok mana yang terbaik menurut pengamatan siswa dengan memberi kesempatan pada masingmasing ketua kelompok menilai hasil kerja kelompok. Peneliti memberikan penghargaan dengan memberikan pujian pada kelompok yang terbaik.

Pada saat yang sama, kolaborator melakukan pengamatan dengan mengisi 
instrumen yang sudah disiapkan meliputi: pengamatan kegiatan guru, pengamatan kegiatan siswa saat kegiatan belajar mengajar.

Peneliti memberikan tes hasil belajar dengan menggunakan jam pelajaran pada pertemuan berikutnya. Kemudian, guru meminta siswa mengisi angket refleksi terhadap pembelajaran yang telah dilakukan. Hasil yang didapat dari pengamatan ini adalah sebagai berikut:

\section{- Hasil Observasi Kinerja Guru}

Pengamatan kemampuan guru dalam pengelolaan pembelajaran pada pertemuan kedua siklus II dengan skor terendah 3 dan skor tertinggi 4.

\section{- Hasil Observasi Aktivitas Siswa}

Pengamatan aktivitas siswa pada siklus II sudah sangat baik dengan skor terendah 3 dan skor tertinggi 4 (lampiran ).

\section{- Hasil Belajar Siswa}

Setelah dilakukan analisis data hasil tes siklus II dengan materi pelajaran, diperoleh nilai rata-rata siswa sebesar 79,02 Siswa yang tuntas sebanyak 30 orang $(93,75 \%)$, dengan nilai tertinggi 100 dan nilai terendah 60 seperti pada (Lampiran ).

\section{- Hasil Analisis Angket Siswa}

Tanggapan siswa tentang pembelajaran dilakukan pada setiap akhir siklus. Hasil tanggapan siswa atas pembelajaran yang telah dilakukan pada siklus II dapat dilihat pada tabel berikut:
Tabel 6. Hasil Angket Refleksi Siswa pada Siklus II

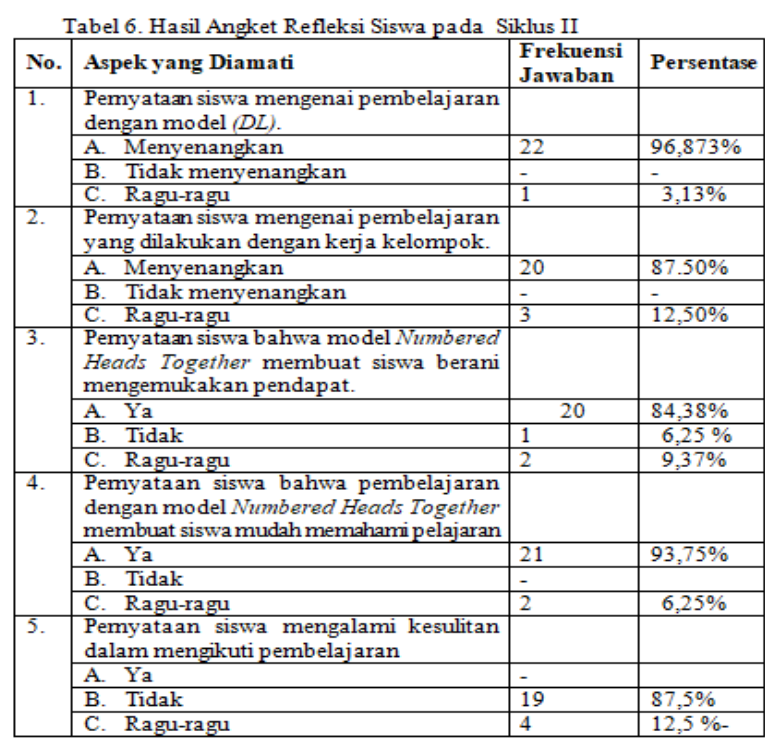

\section{B. Pembahasan Siklus II}

\section{a. Aktivitas Guru}

Pencapaian hasil belajar siswa yang diharapkan seperti yang ditetapkan dalam indikator keberhasilan tidak terlepas dari peran guru dalam proses pembelajaran, mengingat guru merupakan salah satu komponen yang mempengaruhi hasil belajar siswa. Berdasarkan hasil lembar aktivitas guru pada siklus II, dapat diketahui guru semakin matang dalam menerapkan model pembelajaran DL. Guru sudah melakukan perbaikan-perbaikan seperti pemerataan bimbingan pada setiap kelompok, tidak mendominasi pembelajaran dengan memberi kesempatan pada siswa untuk terbiasa berpikir sendiri, serta sudah dapat mengatur alokasi waktu dengan baik.

b. Aktivitas Siswa 
Pada siklus II aktivitas siswa lebih meningkat lagi dibandingkan dengan siklus I. Ditandai dengan perolehan skor hasil observasi yang tinggi yaitu sebesar 3 dan 4 Hal ini .menunjukkan siswa dalam melakukan aktivitas yang diharapkan lebih banyak dibandingkan dengan siklus I. Siswa sudah lebih terarah pada kerjasama kelompok, meningkatnya diskusi dan tanya jawab dalam kelompok serta lebih berani dalam mengungkapkan pendapatnya, ditandai dengan adanya siswa yang bertanya serta menjawab pertanyaan. Siswa juga telah bekerja sama dengan kelompoknya secara baik, siswa yang pandai sudah mulai menularkan idenya kepada siswa lain yang masih kurang, sehingga semua anggota kelompok memahami diskusi. Hal ini sudah sesuai dengan apa yang diharapkan dalam pembelajaran DL bahwa siswa menyatukan pendapatnya terhadap jawaban pertanyaan / tugas dari guru dan meyakinkan tiap anggota dalam timnya mengetahui jawaban itu. Siswa yang ditunjuk untuk menyajikan hasil diskusi sudah terlihat menguasai materi. Ini berarti bahwa pembelajaran DL sudah dapat terlaksana dengan baik.

\section{c. Hasil Belajar Siswa}

Dari hasil tes pada siklus II terdapat peningkatan. Hal ini dapat terlihat dari rata-rata hasil tes yang diberikan kepada siswa pada siklus II adalah sebesar 79,02. Ketuntasan belajar secara klasikal sebesar 93,75\% atau sebanyak 30 orang memperoleh nilai $\geq 70$.
Dengan demikian hasil belajar pada siklus II ini sudah melampaui indikator keberhasilan yang ditetapkan, sehingga tidak perlu dilakukan siklus selanjutnya. Rinciannya sebagai berikut:

Tabel 7. Ketuntasan Belajar Siswa Hasil Siklus II

\begin{tabular}{|c|l|l|c|}
\hline \multirow{2}{*}{ No } & \multirow{2}{*}{ Ketuntasan } & \multicolumn{2}{|c|}{ Jumlah Siswa } \\
\cline { 3 - 4 } & & Jumlah & Persen \\
\hline 1 & Tuntas & 21 & $93,75 \%$ \\
\hline 2 & Belum Tuntas & & $6,25 \%$ \\
& & 2 & \\
\hline \multirow{2}{*}{ Jumlah } & 23 & $100 \%$ \\
\hline
\end{tabular}

Berdasarkan tabel jumlah yang tuntas adalah 23 orang dan yang tidak tuntas hanya 1 Orang siswa $(4,16 \%)$.

Tabel 8 Keadaan Nilai Hasil Tes Siklus II

\begin{tabular}{|l|l|c|}
\hline No & \multicolumn{1}{|c|}{ Keterangan } & Nilai \\
\hline 1 & Nilai Tertinggi & 100 \\
\hline 2 & Nilai Terendah & 60 \\
\hline 3 & Nilai Rata-rata & 79,02 \\
\hline
\end{tabular}

Berdasarkan tabel 14, menunjukkan bahwa nilai tertinggi adalah 100, nilai terendah 60 , sedangkan rata-rata kelas adalah 79,02

\section{d. Hasil Angket Siswa}

Pada siklus II, secara umum siswa memberikan respon positif atas pembelajaran yang telah dilakukan. Sebanyak 96,873\% siswa mengaku merasa senang dengan pembelajaran discovery learning, $84,37 \%$ siswa terdorong untuk berani mengemukakan pendapat, 93,75\% siswa mengaku mudah memahami pelajaran. Terdapat siswa yang masih mengalami kesulitan dalam mengikuti pembelajaran serta 
kurang berani mengemukakan pendapat, namun persentasenya kecil.

Dari pembahasan silklus I dan II diatas menunjukkan bahwa indikator keberhasilan tercapai, yaitu aktivitas siswa meningkat dari baik menjadi semakin baik, rata-rata hasil belajar siswa pada siklus I 64,81 siklus II 79,02 yang berarti bahwa indikator keberhasilan untuk meningkatkan aktivitas dan hasil belajar siswa pada materi Kugapai rezekimu dengan ikhtiarku melalui model Pembelajaran Discoveri Learning ( DL ) di kelas VIII A MTsN 2 Pidie Jaya.

\section{SIMPULAN}

Hasil belajar siswa kelas VIII A semester ganjil MTsN 2 Pidie Jaya pada materi pokok Kugapai rezekimu dengan Ikhtiarku dapat ditingkatkan melalui model pembelajaran discovery learning ditunjukkan oleh peningkatan rata-rata nilai tes akhir siswa dari 62,81 pada siklus I menjadi 78,75 pada siklus II, dan ketuntasan belajar siswa meningkat dari 65,62\% pada siklus I menjadi 93,75 pada siklus II.

Keaktifan dan motivasi kelas VIII A semester 1 MTsN 2 Pidie Jaya pada materi pokok Kugapai rezekimu dengan Ikhtiarku dapat ditingkatkan melalui model pembelajaran discovery learning. ini ditunjukkan dengan persentase Keaktifan siswa 58,64\% pada siklus I meningkat menjadi $86,36 \%$ pada siklus II. 


\section{DAFTAR PUSTAKA}

a. Arends, Richard.I. 2008. Belajar untuk Mengajar (terjemahan). Edisi Ketujuh. Buku Dua. Yogyakarta: Pustaka Pelajar.

b. Kementerian Agama, 2014. Al-Qur'an Hadits,Kelas VIII, Jakarta, Inpektorat Kementerian Agama

c. Abdul Wadud, 2015. Al-Qur'an Hadis ,Madrasah Tsanawiyah Kelas VIII.Cet.1-Semarang: PT.Karya Toha Putra.

d. Nur Hadi,Sunariyah, 2017. Ayo Memahami Al-Qur'an dan Hadis untuk MTs Kelas VIII, Semarang:Erlangga.

e. Departemen Pendidikan Nasional, 2006. Peraturan Menteri Pendidikan Nasional Tentang Standar Isi. Jakarta: Depdiknas.

f. Herdiansyah, 2009. Model Pembelajaran Kooperatif Tipe NHT. http://herdy07.wordpress.com/2009/04/22/model-pembelajaran-nht-numbered-headtogether/.

g. Ibrahim, M, dkk., 2000. Pembelajaran Kooperatif. Surabaya: University Press.

h. Jacobsen, David A, dkk, 2009. Metode-Metode Pengajaran (terjemahan). Edisi Kedelapan. Yogyakarta: Pustaka Pelajar.

i. Junus, Mahmud, 1984. Tarjamah Al-Qur'an Al-Karim. Bandung: PT Al-Ma’arif.

j. Kusumah, Wijaya, 2010. Mengenal Penelitian Tindakan Kelas. Jakarta: PT Indeks.

k. Muhibbinsyah, 2010. Psikologi Pendidikan dengan Pendekatan Baru. Edisi Revisi. Bandung: PT Remaja Rosdakarya.

1. Nurhadi, dkk., 2003. Pembelajaran Kontekstual dan Penerapannya dalam KBK Malang: Universitas Negeri Malang.

m. Slavin, Robert E, 2009. Psikologi Pendidikan Teori dan Praktek (terjemahan). Edisi Kedelapan. Jilid 2. Jakarta: PT.Indeks

n. Suharjono, 2010. Pertanyaan dan Jawaban Seputar Penelitian Tindakan Kelas dan Penelitian Tindakan Sekolah. Malang: Cakrawala Indonesia dan LP3 Universitas Negeri Malang.

o. Sukardi, 2003. Metodologi Penelitian Pendidikan. Yogyakarta: Bumi Aksara.

p. Uno, B., Hamzah. 2010. Model Pembelajaran, Menciptakan Proses Belajar Mengajar yang Kreatif dan Efektif . Jakarta: Bumi Aksara. 